\title{
Leinster cave seismic risk management: a block cave solution
}

\author{
M Hopkins BHP, Australia
}

R Rimmelin BHP, Australia

A Landon BHP, Australia

\begin{abstract}
On 31 October 2013, production at Leinster's sublevel caving (SLC) operations were suspended following a significant mining-related seismic event that caused unforeseen levels of damage to underground workings. The event occurred when mining was taking place in an area known as the 11 Level Fold, approximately $1,100 \mathrm{~m}$ below surface.

An assessment of the seismic risk following the 2013 event determined that it was too significant to continue with the SLC operations. Therefore, the SLC operations were not restarted and alternate mining methods would need to be investigated to address the exposure of personnel to the effects of the seismic concentration associated with the 11 Level Fold area.

The proposed solution avoids the zones of highest seismic activity by transitioning to a block cave mining method and locating a production footprint at a level where interaction with the previous SLC and the 11 Level Fold can be avoided. This design is based on an advance undercut and excavation of 22 drawbells. Due to a significant regional shear that vertically bisects the orebody, it is expected that a 'chimney' cave will develop, thereby connecting with the previous sublevel cave column. The design will maintain critical infrastructure, such as the existing shaft, and use the current decline infrastructure to access the new production level.
\end{abstract}

This work shows how high seismic risk can be managed by defining seismic exclusion zones and employing a mine design and mining method that best accounts for the geotechnical environment.

Keywords: seismic risk, sublevel caving, block caving, mine design

\section{Introduction}

The Perseverance underground mine is part of BHP's Leinster Nickel Operations (NLN) located $645 \mathrm{~km}$ northeast of Perth in Western Australia (Figure 1). The operations consist of concentrator and tailings storage facilities, the Perseverance underground mine, the Venus underground mine project and the Rocky's Reward open cut.

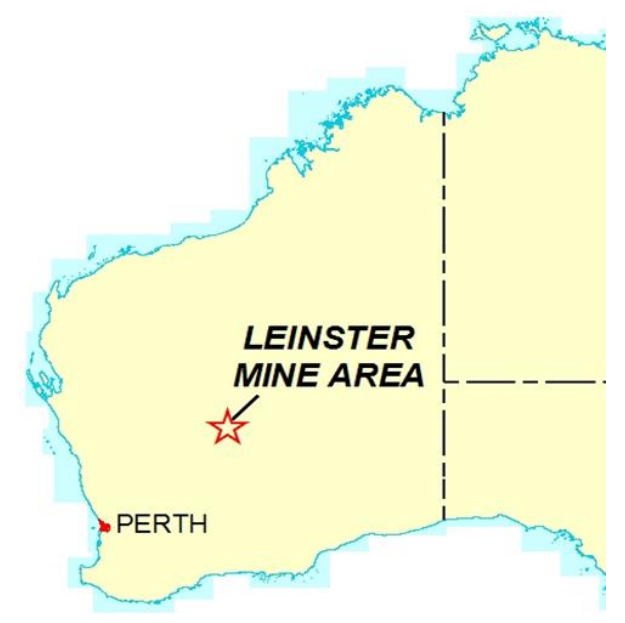

Figure 1 Location of the Leinster mine area inclusive of the Perseverance underground mine 
Underground mining at Perseverance first commenced in 1978 with ore extracted via various methods until 1986 when the mine was placed on care and maintenance. Mining resumed in 1989 via open cut methods until 1995, while the underground workings were re-established and extended in preparation for sublevel cave (SLC) mining (Tyler \& Werner 2004). SLC mining continued uninterrupted until 31 October 2013 when a significant mining-related seismic episode resulted in extensive damage to underground workings and suspension of the SLC mining operations. Prior to the 2013 event, this resource was planned to be extracted via a conventional SLC method. However, given the extensive damage from the 2013 event and the high potential for reoccurrence of a similar event, the seismic hazard was considered too high to continue with the SLC plan.

Underground mining resumed in 2015 with mining of the $1 \mathrm{~A}$ orebody, a sub-vertical massive sulphide lode, via open stoping methods (Figure 2). The Perseverance underground workings currently extends to a depth of 1,340 $\mathrm{m}$ below surface and is serviced by a decline and a shaft that provides hoisting and second means of personnel egress.

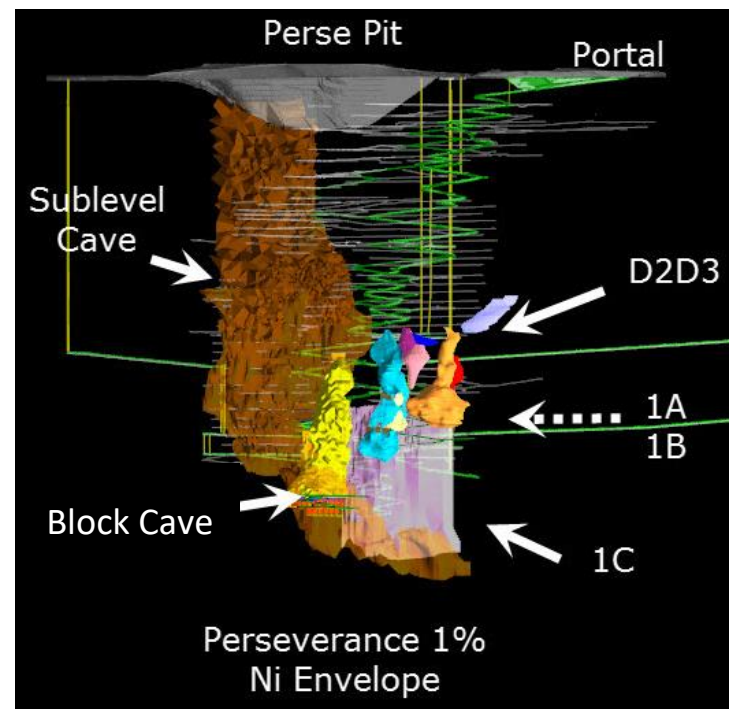

Figure 2 Perseverance mine long section (looking west)

A significant disseminated Nickel resource still exists below the 11 Level SLC workings $(1,100 \mathrm{~m}$ below surface). Recent studies have determined that a block cave mining method that removes personnel from the most hazardous areas of the mine while remotely targeting the ore above is deemed the safest option for extracting this resource.

This paper provides a case study of how significant seismic risk can be managed by employing a mine design and mining method that best accounts for the geotechnical environment.

\section{Geology and geomechanical environment}

\subsection{Geology}

The Perseverance deposit is a komatiite-hosted nickel sulphide resource occurring on the eastern margin of the Agnew-Wiluna greenstone belt. Locally, the Perseverance mine geology comprises a main ultramafic nickel disseminated orebody with associated massive sulphide layers and structurally remobilised and constrained massive sulphide lenses (1A, 1B, 1C shoots). Mine-scale stratigraphy comprises a dominantly felsic footwall sequence of variably altered volcanic and volcaniclastic rock with minor mafic units truncated by the Perseverance ultramafic complex. A Proterozoic dolerite dyke strikes east-west and dips $75^{\circ}$ sub-north cutting through the older north-south trending stratigraphy (Figure 3 ). 


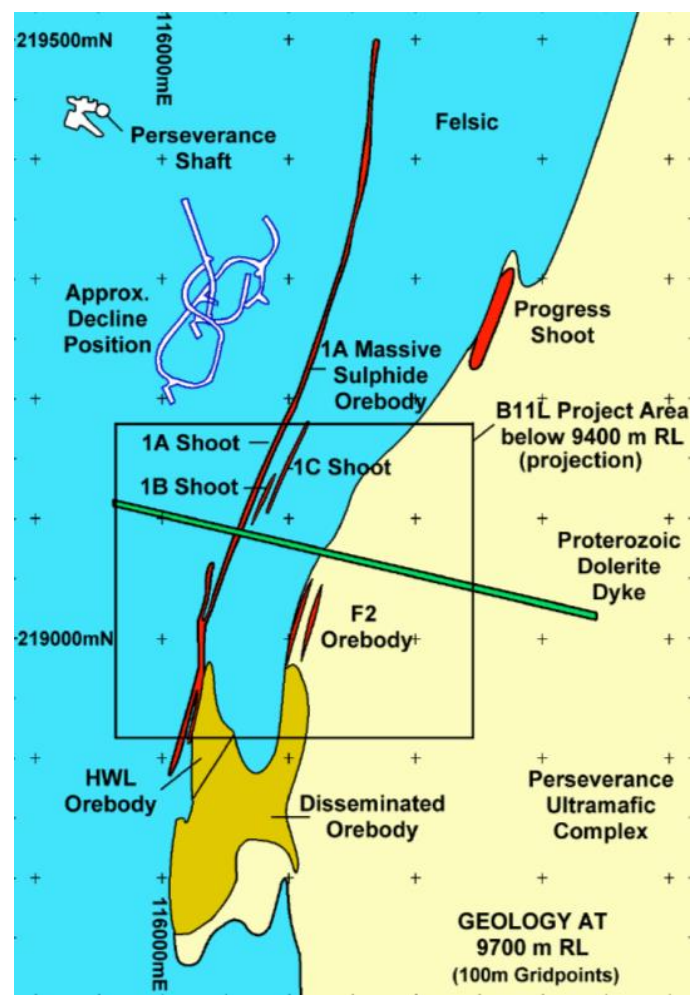

Figure $3 \quad$ Plan of geology at $9,700 \mathrm{mRL}$

Metamorphism has occurred to lower amphibolite facies affecting the Perseverance region, with the felsic lithologies altering to chlorite-biotite-actinolite assemblages and the ultramafic sequences serpentinised with varying degrees of talc-carbonate alteration. Olivine is preserved in some areas towards the east of the disseminated orebody.

Perseverance has experienced a number of deformation events of varying significance that have affected the local stratigraphy. A significant thrusting event, focused along the margin of the felsic ultramafic contact, resulted in creation of the Hangingwall Limb orebody $(H W L)$ and the felsic nose, further resulting in a zone of highly strained rock known as the Hangingwall Shear (HWS) or 1A fault.

Figures 4 displays the D1 event folding that offsets the orebody at 1,100 m below surface, known as the mining 11 Level. The offset is in the order of $100 \mathrm{~m}$ to the north resulting in the main Perseverance disseminated orebody being overlain by the felsic volcanics.

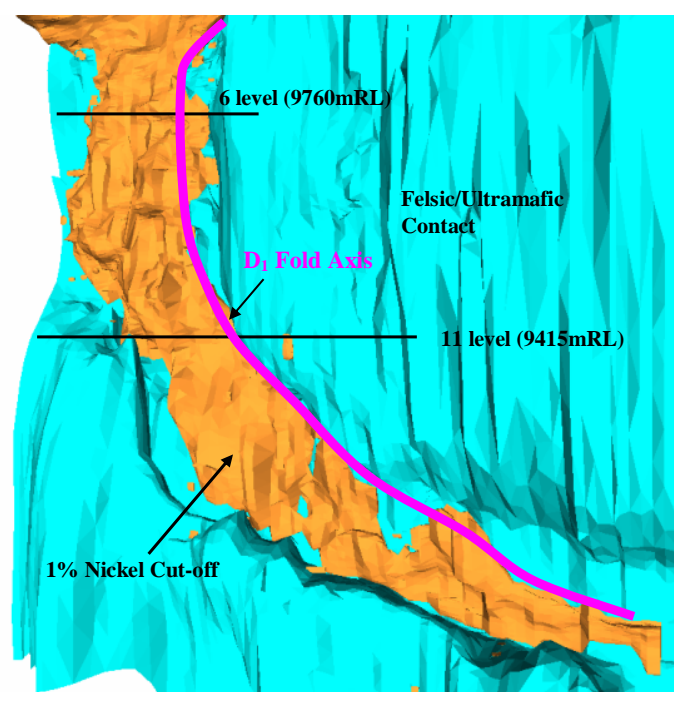

Figure 4 Disseminated orebody and (mining) hanging wall contact (looking west) 


\subsection{Geomechanical environment}

The geomechanical environment for the Perseverance mine is complex, though well understood, with the structural and lithological complexity, as outlined above, resulting in rock types with diverse mechanical response to mining. The ground conditions within the SLC operations have been challenging for a number of years with the experiences and methods used to overcome these challenges previously well documented (Wood et al. 2000; Struthers et al. 2000; Thin et al. 2006; Lessard \& Heal 2009). Difficult conditions are caused by a combination of high horizontal stresses, weak sheared ground within the HWS, weak altered ultramafic rocks, brittle felsic volcanic rocks and seismically active structures.

Between 2006 and 2009, pre-feasibility and feasibility studies were undertaken where specific knowledge of the disseminated orebody beneath 1,100 $\mathrm{m}$ was developed. The program consisted of diamond core logging for geotechnical and structural parameters, intact rock property testing and stress measurements.

A Mining Rock Mass Model (MRMM) was developed to assist in characterising and highlighting domains throughout the mining precinct. The MRMM comprises rock mass classification systems including the Rock Tunnelling Quality Index (Q, Barton et al. 1974), Laubscher's (1990) Rock Mass Rating (RMR) and the Geological Strength Index (GSI, Hoek et al. 1995). Five geotechnical domains have been identified (Figure 5): Felsic, HWS, Serpentinite, Transitional and Olivine.

Ground conditions are generally poor to fair, with the exception of the HWS which is a zone of very poor quality, intensely fractured ground that is prone to unravelling failure. The range of rock mass classification ratings for each domain are displayed in Table 1 . Intact rock mechanical properties are dependent on the degree of serpentinite alteration and structural disturbance, as evidenced in Table 2.

The structural model was developed for the hanging wall rock mass identifying the major structures that were likely to influence mining below 11 Level. Structural properties are given in Table 3 and locations in relation to the cave foot print in Figure 5.

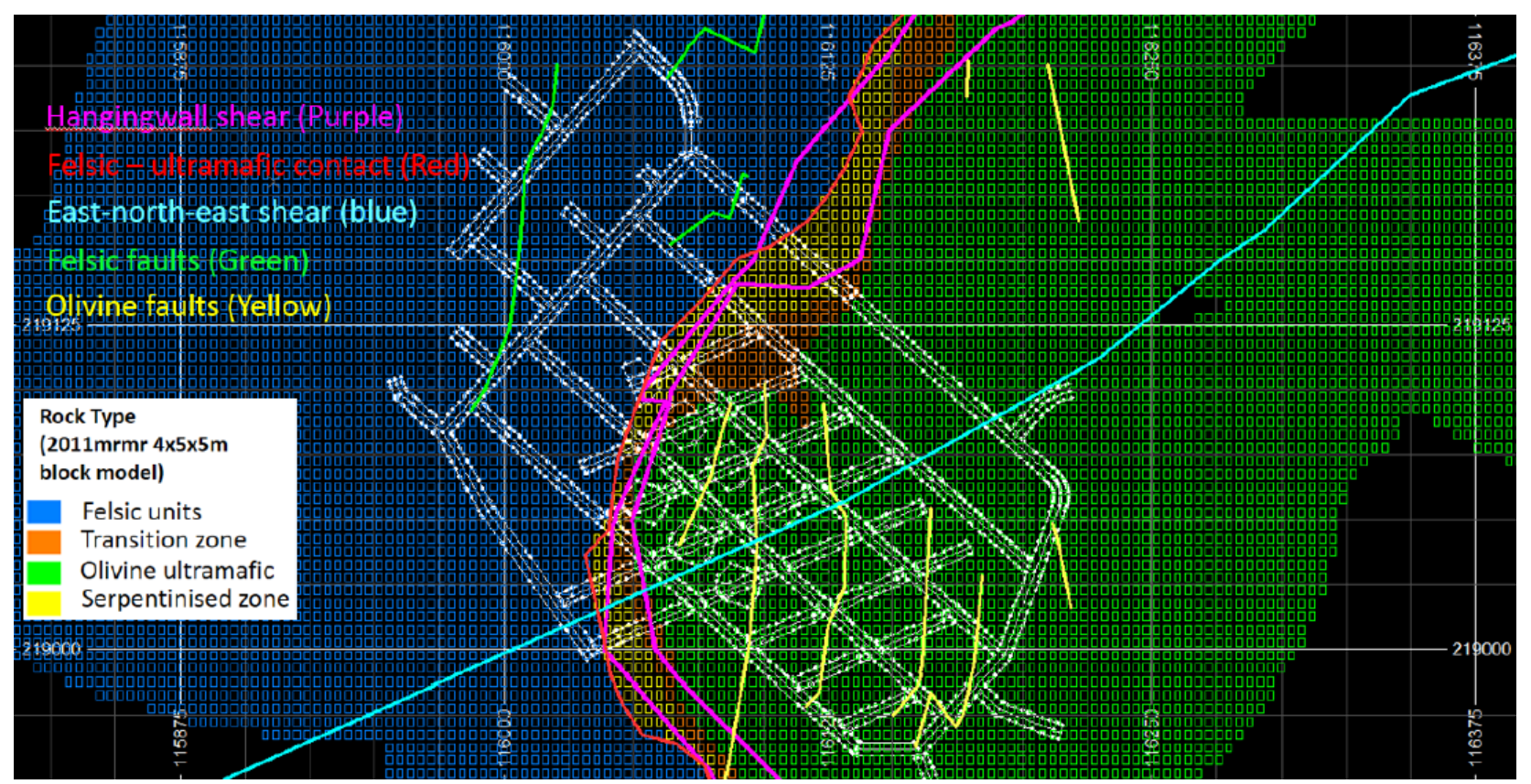

Figure 5 Spatial association between the five primary geotechnical domains at the extraction level 
Table 1 Summary of rock mass quality for each geotechnical domain

\begin{tabular}{|c|c|c|c|c|c|}
\hline Rock unit & Joint condition & GSI & $\mathbf{Q}^{\prime}$ & $\mathbf{Q}$ & RMR \\
\hline \multirow[t]{2}{*}{ Felsic } & \multirow{2}{*}{$\begin{array}{l}\text { Rough and undulating with } \\
\text { no infill. Few occurrences of } \\
\text { mica infill when foliated }\end{array}$} & $54-72$ & $10.8-31.9$ & $1-3.1$ & $52-68$ \\
\hline & & Average 63 & Average 20 & Average 1.9 & Average 59 \\
\hline \multirow[t]{2}{*}{ Serpentinite } & \multirow{2}{*}{$\begin{array}{l}\text { Polished to smooth and } \\
\text { undulating. Tochillinite infill } \\
\text { with shearing }\end{array}$} & $46-62$ & $3.4-11.5$ & $0.3-1.2$ & $44-59$ \\
\hline & & Average 53 & Average 9.9 & Average 1 & Average 50 \\
\hline \multirow[t]{2}{*}{ Transitional } & \multirow{2}{*}{$\begin{array}{l}\text { Smooth and undulating to } \\
\text { rough and undulating. } \\
\text { Tochillinite infill }\end{array}$} & $52-69$ & $5.1-24.5$ & $0.5-2.3$ & $51-64$ \\
\hline & & Average 61 & Average 16.5 & Average 1.6 & Average 57 \\
\hline \multirow[t]{2}{*}{ Olivine } & \multirow{2}{*}{$\begin{array}{l}\text { Smooth and planar to } \\
\text { rough and undulating. } \\
\text { Tochillinite infill }\end{array}$} & $54-69$ & $5.4-25$ & $0.5-2.4$ & $53-66$ \\
\hline & & Average 62 & Average 16.5 & Average 1.6 & Average 59 \\
\hline
\end{tabular}

Table 2 Summary of average property test results for each geotechnical domain

\begin{tabular}{|c|c|c|c|c|c|}
\hline Rock domain & $\begin{array}{l}\text { Unit weight } \\
\left(\mathrm{kN} / \mathrm{m}^{3}\right)\end{array}$ & $\begin{array}{l}\text { Uniaxial } \\
\text { compressive } \\
\text { strength (MPa) }\end{array}$ & $\begin{array}{l}\text { Uniaxial tensile } \\
\text { strength (MPa) }\end{array}$ & $\begin{array}{l}\text { Young's } \\
\text { modulus (GPa) }\end{array}$ & $\begin{array}{l}\text { Poisson' } \\
\text { s ratio }\end{array}$ \\
\hline Felsic & 27.1 & 187 & 14 & 63 & 0.26 \\
\hline Serpentinite & 27.8 & 113 & 8 & 45 & 0.40 \\
\hline Transitional & 30.5 & 150 & 10 & 74 & 0.37 \\
\hline Olivine & 32.7 & 159 & 11 & 126 & 0.31 \\
\hline
\end{tabular}

Table 3 Significant geotechnical structural characteristics

\begin{tabular}{llll}
\hline Structure & Spacing $(\mathbf{m})$ & Thickness $(\mathbf{m})$ & Dip/dip direction $\left(^{\circ}\right)$ \\
\hline HWS & Single structure & 20 & $\begin{array}{l}\text { Variable - envelope steep } \\
\text { dipping and north-south strike }\end{array}$ \\
D6 structures in felsic & $30-50$ & Variable & $70 / 280$ \\
D6 structures in olivine & 40 & $0.1-3$ & $85 / 110$ \\
\hline
\end{tabular}

The in situ stress field was defined through a combination of direct stress measurements and acoustic televiewer surveys for borehole breakout. These were compared to the results of existing historical depth equivalent Commonwealth Scientific and Industrial Research Organisation (CSIRO) HI Cell measurements, obtaining a close correlation between the three methods.

The stress measurement results indicate a relatively consistent relationship between stress magnitude and depth for the three principal stresses (Figure 6). This shows the deviatoric nature of the stress regime with the S1 principal stress 2.5 times the overburden stress. 


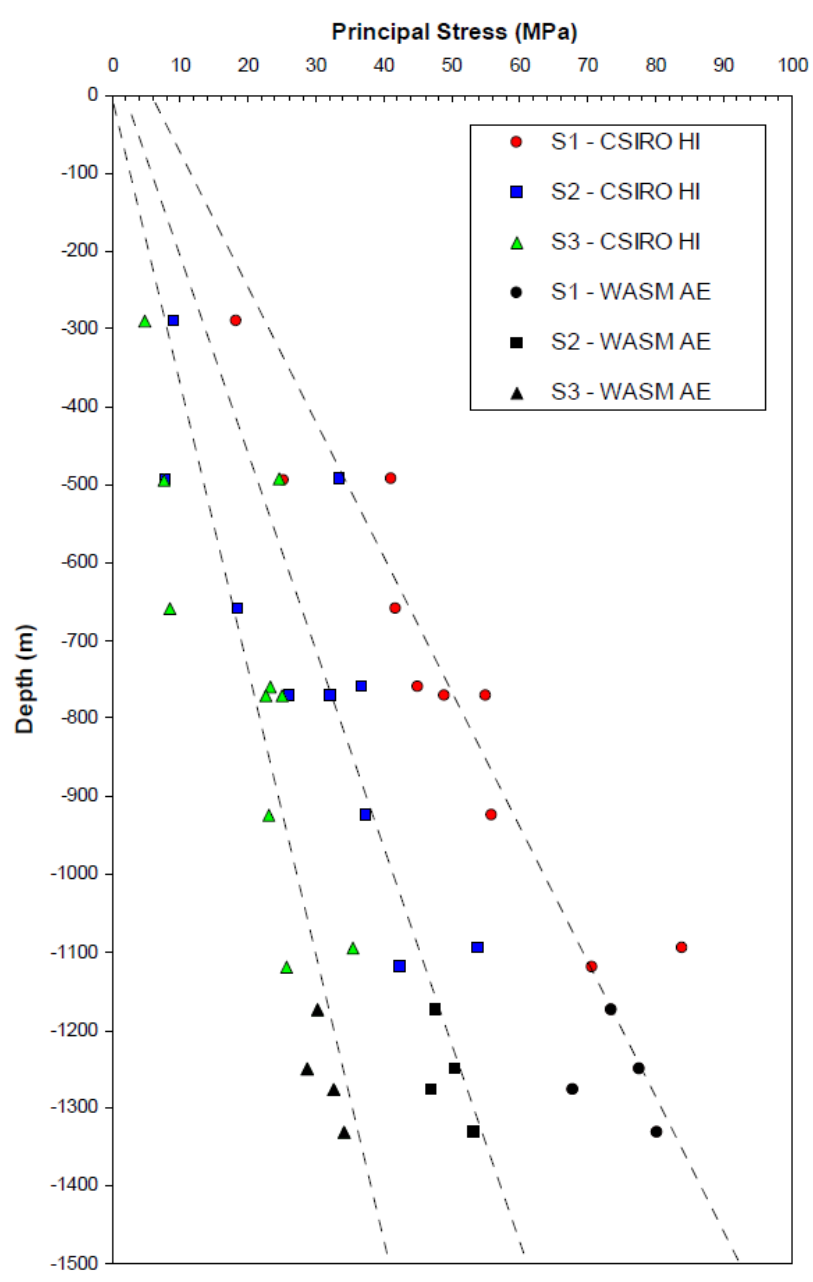

Figure 6 Relationship of principal stress magnitudes with depth

The orientation of the major principal stress is $230^{\circ} \pm 30^{\circ}$ between 1,100 and $1,400 \mathrm{~m}$ below the surface (Figure $7(b)$ ), which shows a rotation in principal stress components from those above 11 Level (Figure 7(a)). The rotation in stress is attributed to the complex structural geology that occurs at and below the 11 Level Fold.

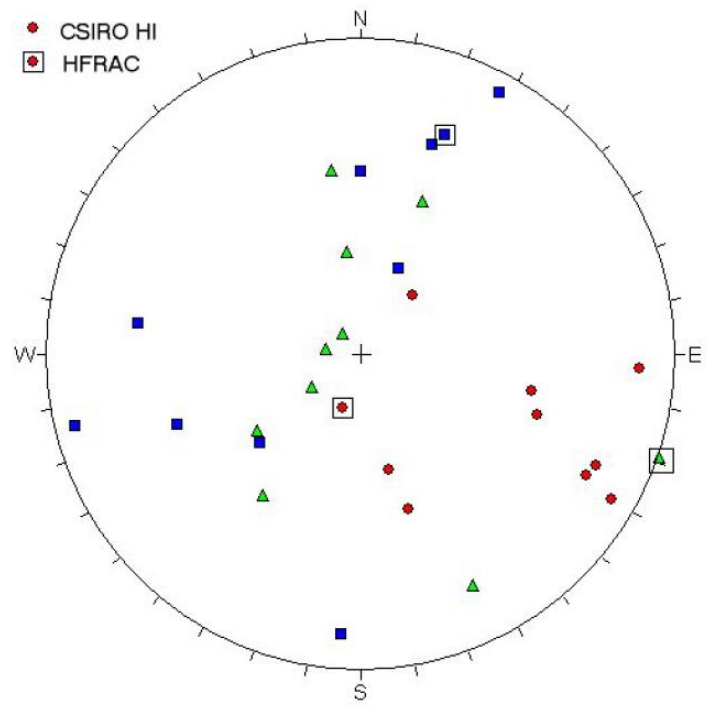

(a)

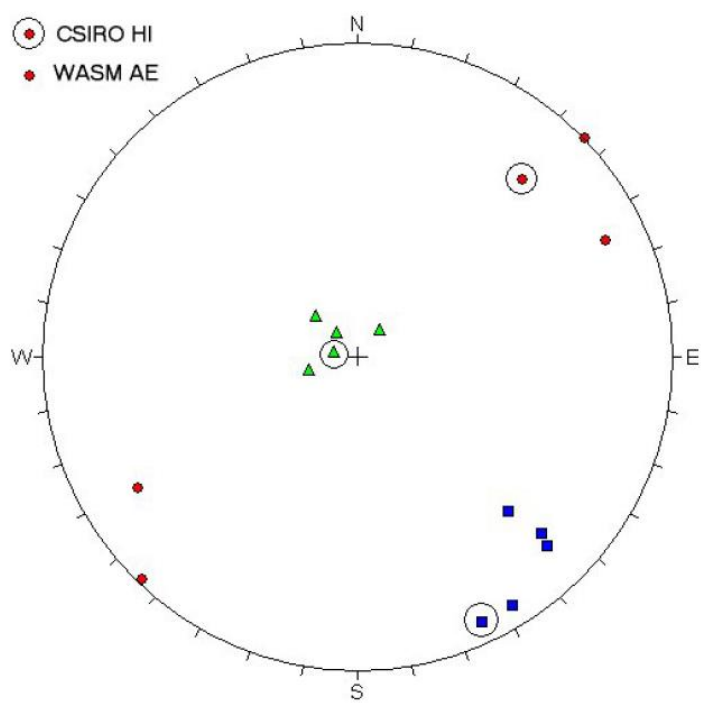

(b)

Figure 7 (a) Principal stress orientations above 11 Level; and, (b) Principal stress orientations below 11 Level 


\section{$3 \quad$ Seismic risk}

The Perseverance mine has a history of dynamic ground events associated with felsic volcanic and intrusive rocks of the geological footwall (Lessard \& Heal 2009). These events range from strainbursting during development to shakedown events in under-reinforced infrastructure, and rockbursts associated with mine-scale faulting. Lessard and Heal (2009) described the main sources of seismicity at Perseverance:

- Intact rock fracturing and shearing on geological structures below the SLC. Extraction of the cave would develop a seismogenic zone 50 to $75 \mathrm{~m}$ in advance of the current production front. Events caused by this phenomenon typically did not cause damage, as these were remote to existing mine development, though typically only in the felsic domain.

- Localised strainbursting during development activities within the felsic domain.

- Cave propagation. Small events associated with rock fracturing during cave propagation as material is extracted from production levels.

However, the characteristics of seismicity began to change in the years leading up to cessation of SLC mining, with large, damaging, dynamic events occurring within active mining areas. It was the result of elevated stress induced by ongoing mining at depth and approaching the 11 Level Fold; an area of the mine which has complex geology associated with brittle rock types. Due to the gradual and progressive impacts of mining the SLC, the stresses in this area were increasing, creating a situation where sudden rock failure was possible in multiple locations. The changes in mine stresses are highlighted by the increasing size and frequency of large seismic events in the six months preceding the 31 October 2013 episode (Figure 8).

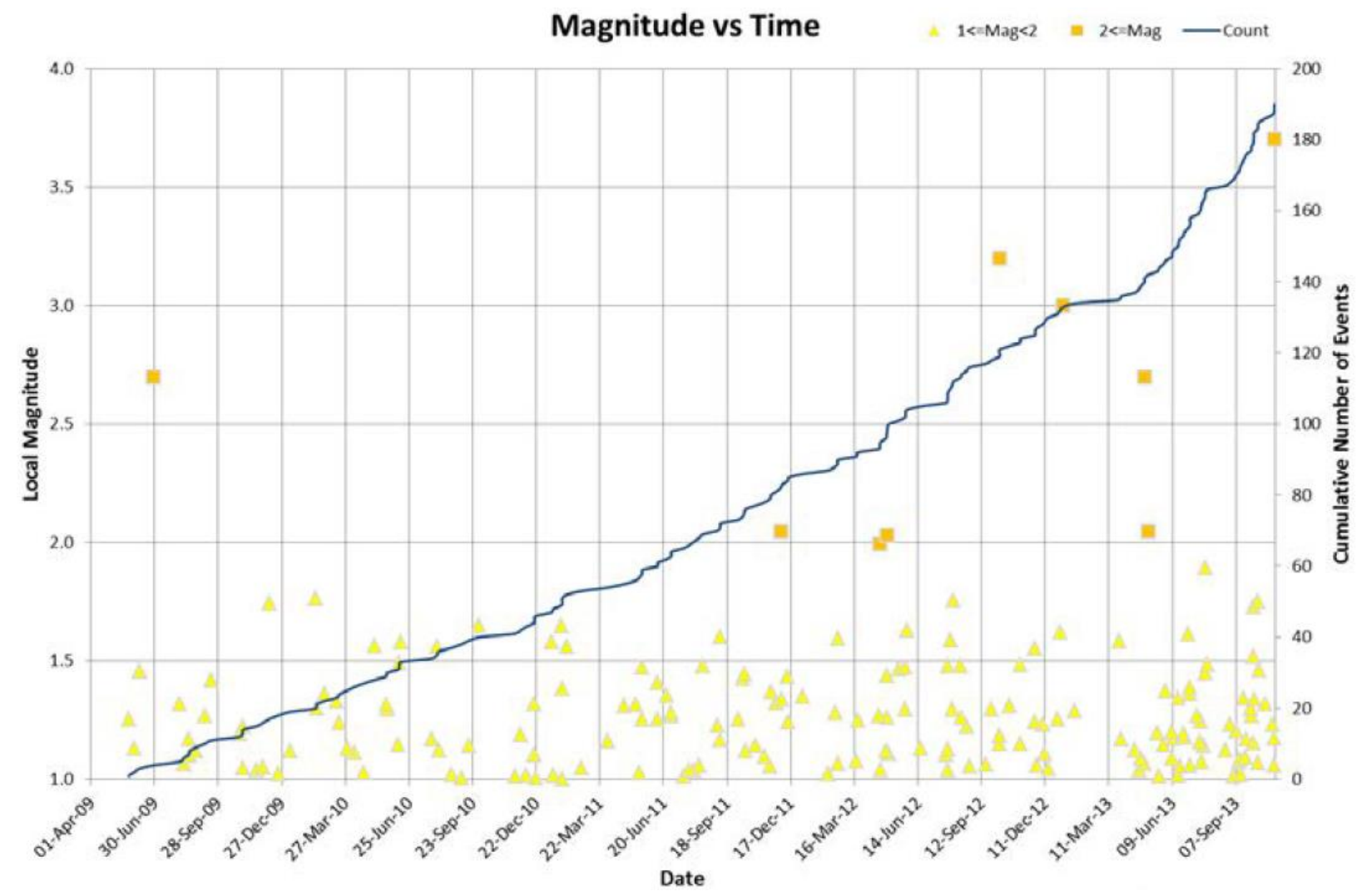

Figure 8 Chart of recorded seismicity at Perseverance (events $>+1$ shown) 


\subsection{October 2013 event}

On 31 October 2013, the Perseverance mine experienced an episode of rock mass instability which resulted in extensive damage to underground workings and suspension of the SLC operations. A +3.7 Richter (local) magnitude event occurred and was centred in the northern abutment between the SLC production levels of 9,465 and 9,440. The resulting damage to excavations was extensive, with some fall of ground (FOG) locations recorded up to $300 \mathrm{~m}$ from the headline event source.

At the time of the event, the northern abutment was subject to high stresses due to the depth of mining, the geometry of excavations, and the cave front approaching the 11 Level Fold (Figure 9). The mine was in the process of extending the production footprint through the fold, towards the northern cave abutment, thereby transitioning into the most highly stressed area of the mine. This resulted in a convergence of discrete seismic event occurrences within active production areas.

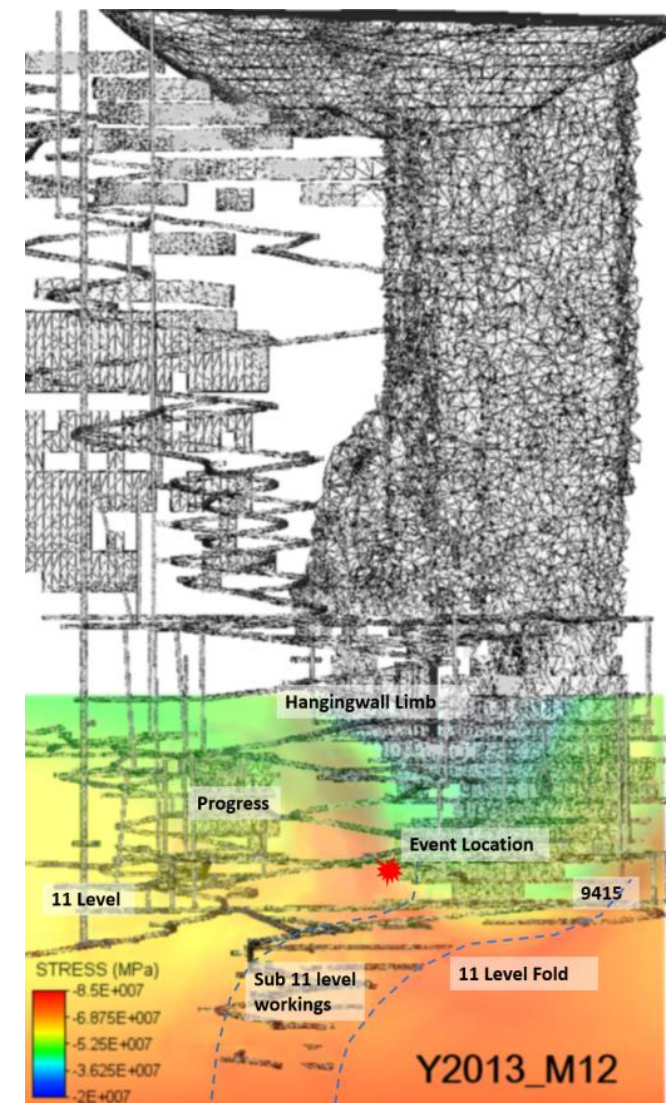

Figure 9 Perseverance SLC-induced stress plot with mining approaching the 11 Level Fold (looking east)

The gradual build-up of mining-induced stresses caused a sudden rock mass failure that resulted in the dislocation of mine-scale structures, shedding load into adjacent mine workings. Figure 10 displays the progression of the rock mass instability episode as evidenced by the evolving seismic response:

1. The northern mining abutment was subject to compressional failure which caused dislocation towards the southeast.

2. The load then transferred onto the contact between the $A Q$ and $A B$ Felsic units, the F2 fault set and the dolerite dyke causing rupture and damage to a number of mine workings.

3. Major structure \#2 ruptured causing dynamic ejection of ground support on the 9465 Level.

4. Further load and dislocation occurred along the $A B$ and $A Q$ Felsic contact. 


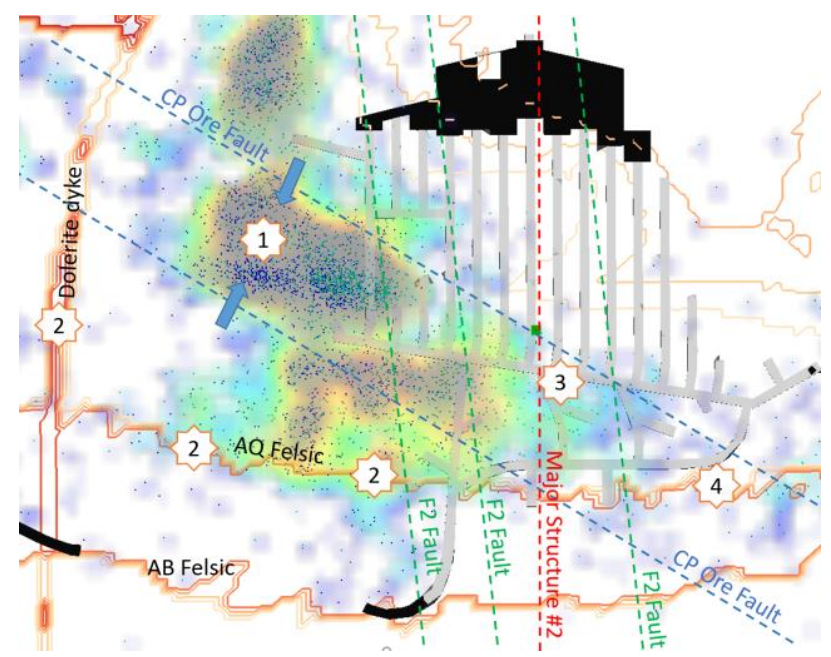

Figure 10 Sequence of global failure mechanism at 9,440 mRL

Ground falls of varying severity were experienced across five sublevels ( $25 \mathrm{~m}$ vertical level spacing) and at two locations on the main decline. Failure mechanisms ranged from shakedowns in under-supported areas to ground ejections at fault intersections (Figure 11). The most intense falls of ground occurred within the level accesses and hanging wall drives, where intersections of mine-scale structures developed localised increases in strain, leading to strainburst and shear displacement.

Mine production was immediately suspended following the 31 October 2013 event.

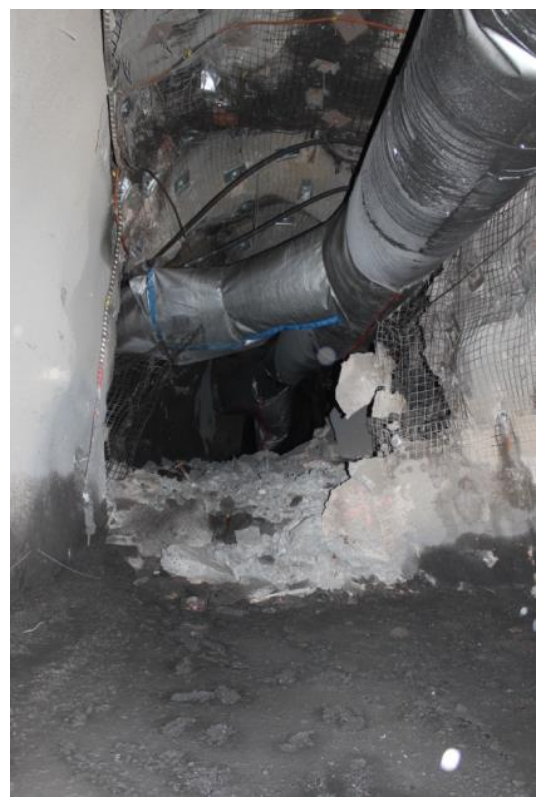

(a)

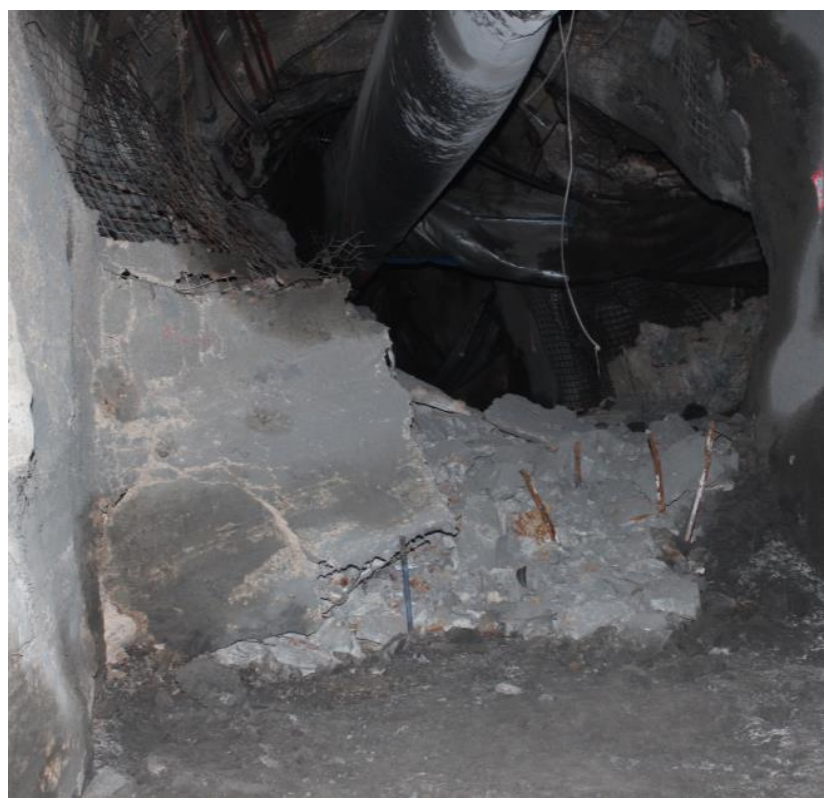

(b)

Figure 11 Ground ejection on 9465 Level; (a) Looking south; and, (b) Looking north

\subsection{Implications for mining through the 11 Level Fold}

Following the 31 October 2013 event, it was apparent that SLC mining could not continue within or through the 11 Level Fold due to the likelihood that a similar mechanism would be generated. An internal BHP assessment of the seismic hazard suggested that the confluence of damaging and temporally unpredictable seismicity and active work areas would create an unacceptable risk. Following this analysis, BHP assessed that it was unable to safely resume the SLC operations at the Perseverance mine. 


\section{$4 \quad$ Modelled rock mass behaviour}

Numerical modelling has been used as a tool for assessing mining options for beneath the 11 Level Fold. The model developed is a three-dimensional coupled non-linear discontinuum finite element numerical model, with Newtonian cellular automata flow (DFE-NCA) (Beck 2013). This model allows the simulation of plastic strain, caused by stress in excess of rock mass strength, with simulations of cave growth and flow. The coupled approach estimates the deformation of different rock types in the caving precinct, as well as the movement of caved material, which can either constrain or make space for further displacement of caving material to occur.

Rock mass material properties within the model have been calibrated using microseismicity data, recorded since 2003, along with various other types of geotechnical monitoring records of excavation damage and strain-related cave growth. As part of the calibration, to ensure suitability for forecasting performance of future mine plans, actual versus modelled seismicity was compared for a six-month period (Figure 12) leading up to the 2013 event. Upon completion, a good correlation between the actual versus modelled forecast results was found, giving confidence towards the approach used to assess future design options.

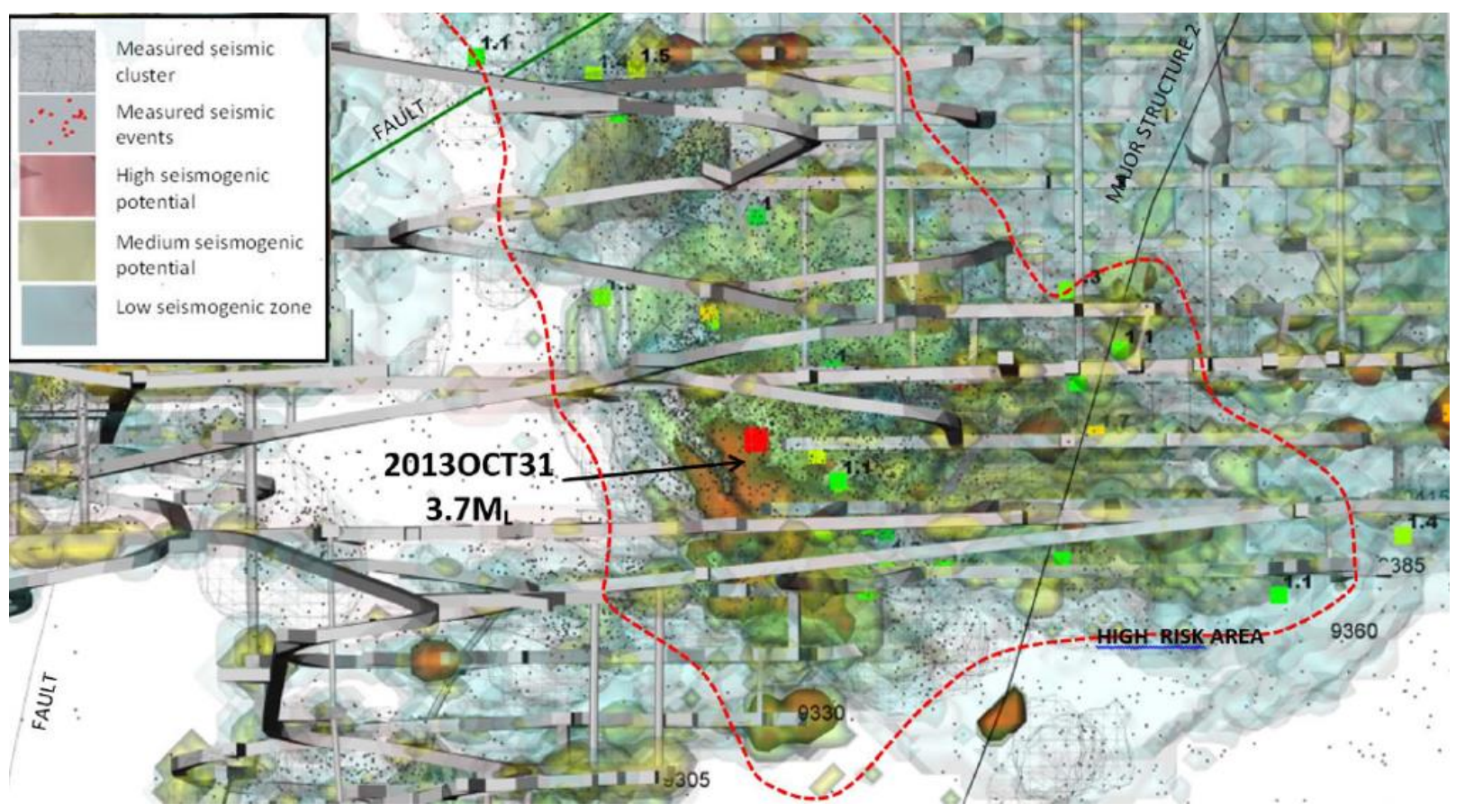

Figure 12 Numerical model forecast seismicity versus actual seismicity (looking east)

Hazards resulting from dynamic rock mass failure when mining at Perseverance have been estimated by reviewing the rate of energy release (RER, Levkovitch et al. 2013), and the degree of deformation; both estimated parameters of the non-linear numerical model. If the estimated deformation is large and the RER is high, there is a greater chance of dynamic rock failure occurring.

While numerical modelling cannot be interpreted to forecast specific events, it is able to be assessed to comparatively forecast seismic and rock mass strain response in mine precincts, when comparing various mine designs and production sequences. However, it is recognised that the results are limited by the quality of the data inputs and capabilities of the software code, and hence the results are not considered absolute. Nevertheless, the numerical model is the best predictive tool available for forecasting rock mass response. Hence, it was chosen as a key tool for developing mine plans for mining below the 11 Level Fold. 


\section{$5 \quad$ Mining below the 11 Level Fold}

Several mining methods had previously been considered for mining beneath the 11 Level Fold precinct, with block cave and sublevel cave options optimised during a pre-feasibility study (Thin 2008).

Although a block cave was the preferred mining method from the pre-feasibility study, due to the lower capital cost, the implementation of the less capital-intensive, though technically feasible, SLC option was pursued. As discussed in Section 3, the resultant seismic hazard conditions were more severe than initially anticipated, which resulted in suspension of mine production from the Perseverance underground.

Investigations and studies into the October 2013 event, and into the seismogenic potential of the zone around the 11 Level Fold have subsequently been carried out (Beck 2017). These studies have focused on identifying a safe and economic method of mining the remaining mineral resources in, and below, the 11 Level Fold. A block cave operation that focuses on mining a small tonnage of high-grade material is considered the best approach to minimise seismicity and deformation.

\subsection{Below 11 Level block cave design}

The Perseverance block cave will be extracted $150 \mathrm{~m}$ below the 11 Level Fold. This mine will leverage off the existing underground decline and hoisting infrastructure, thereby creating a low-capital option for mining the lower Perseverance resource. Mine design criteria has been developed to best manage the geotechnical environment:

- Advanced-undercut with split level, crinkle cut design (apex and undercut levels, see Figures 13 and 14) to maximise pillar thickness and increase stability.

- Level spacing and extraction level crosscut layout to maximise pillar thickness while still providing operability for drill-and-blast.

- West-to-east advance for undercut and drawbell construction to best manage deformation and reduce seismic response by retreating towards a less seismically responsive olivine ultramafic domain.

The extraction level is designed at the elevation of 9,250 mRL. Production will be from 22 drawbells accessed through an offset El Teniente extraction drive layout. More detailed design parameters are provided in Table 4.

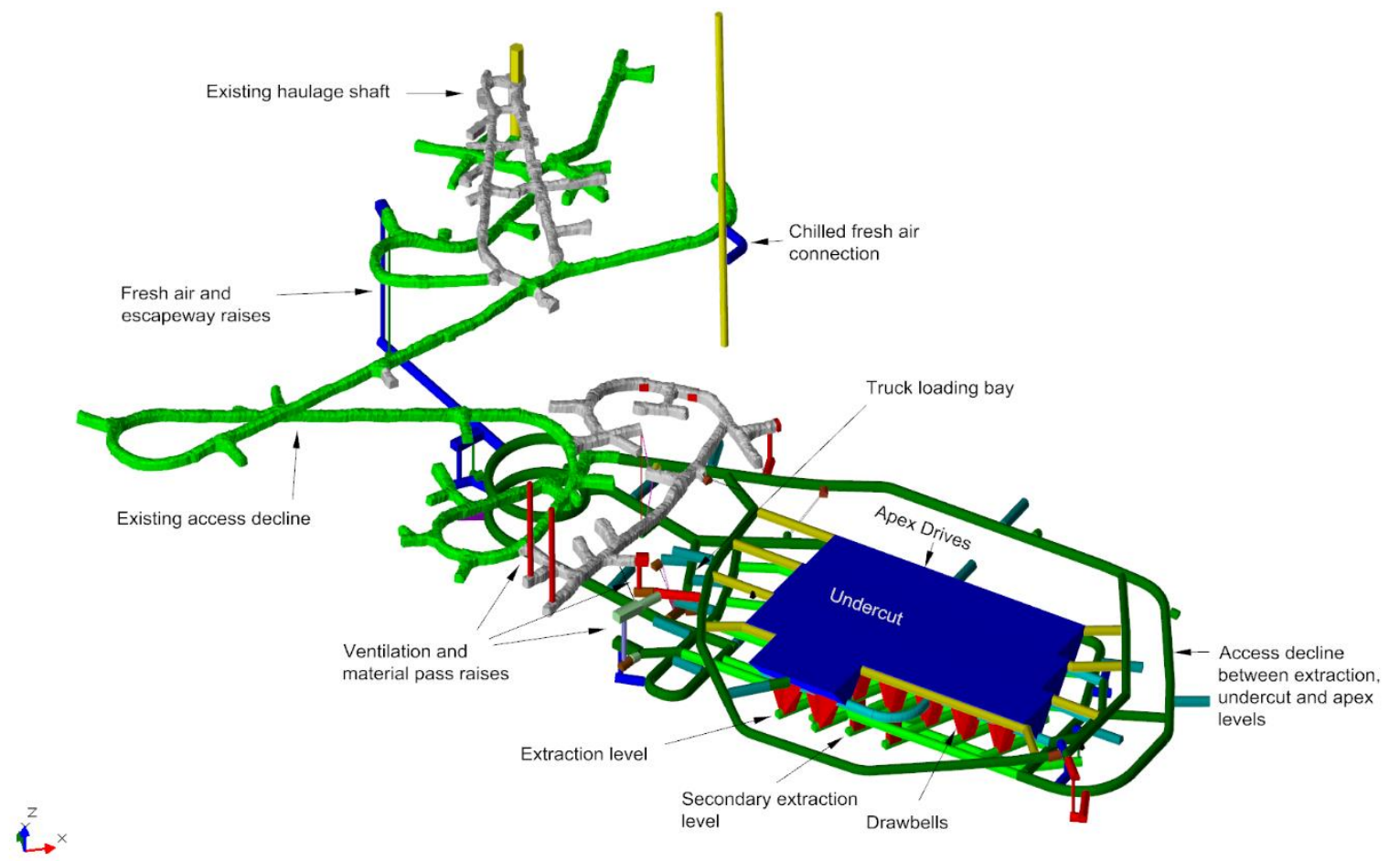

Figure 13 Three-dimensional image of the block cave (proposed) mining area 
Table 4 Extraction level design parameters

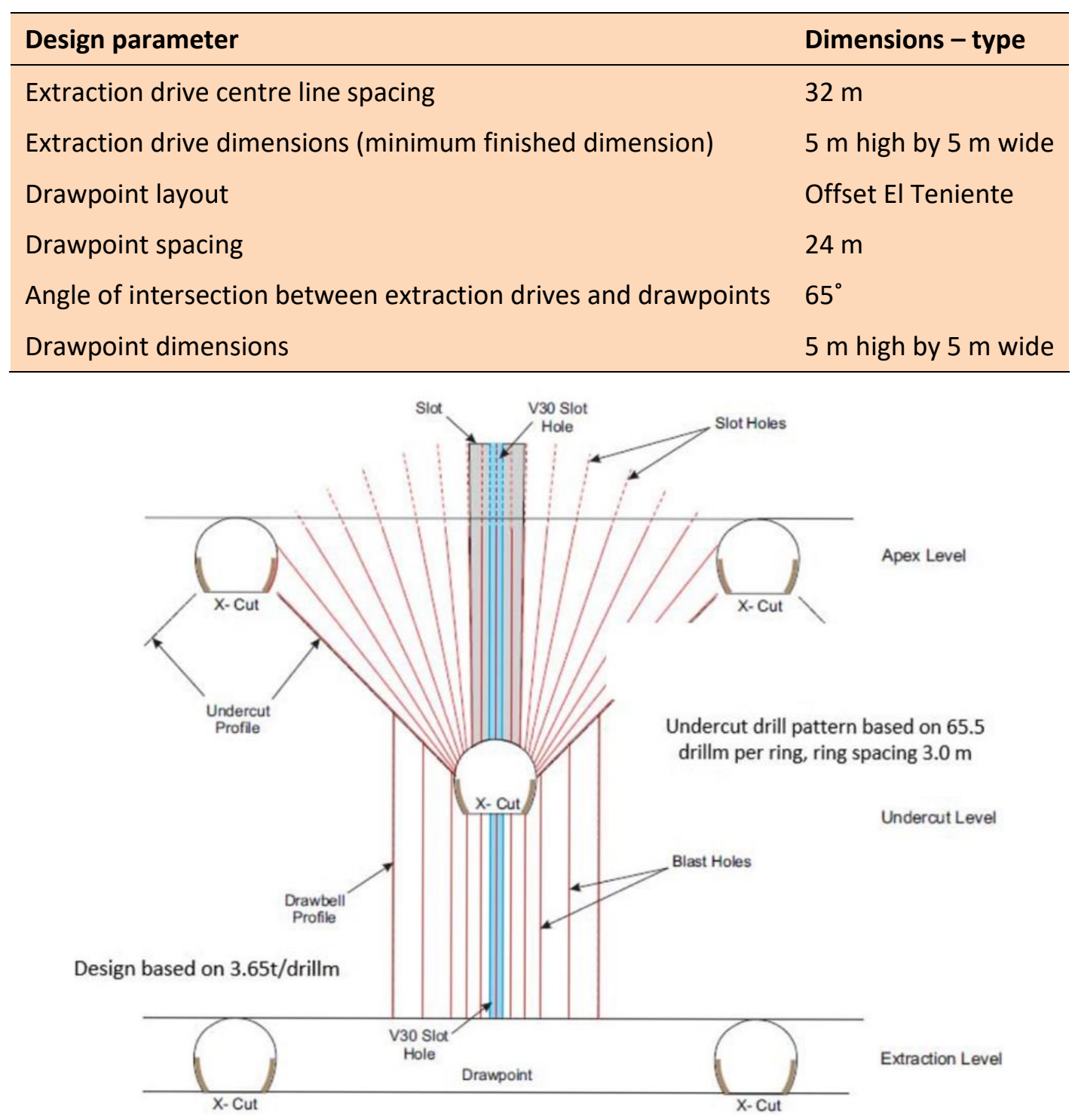

Figure 14 Undercut drilling pattern

\subsection{Seismic risk management with the block cave mining method}

Unlike the SLC method, which would result in work areas coinciding with high levels of seismic risk, a block cave plan is considered the best option because it enables the mine to construct active work areas far enough away from the SLC workings and 11 Level Fold to eliminate stress interactions.

In this method, the seismic response will likely still be high. However, it will be transient, initially spatially associated with the undercut levels before occurring remotely to the active production level. The nature and distribution of the seismicity is outlined in Table 5, which describes the seismic response as block cave milestones are reached. This assessment of the forecast seismic response, when compared to the previous SLC mining method, indicates that the seismic hazard will be effectively managed as the most intense events will occur remotely from the extraction level. 
Table 5 Seismic response milestones for the Perseverance block cave

\begin{tabular}{ll}
\hline Milestone & Seismic response \\
\hline $\begin{array}{l}\text { Initial cave back } \\
\text { instability during } \\
\text { undercutting }\end{array}$ & $\begin{array}{l}\text { Cave back instability will be defined by small, isolated seismogenic zones } \\
\text { close to the undercut back } \\
\text { The seismicity will tend to be constrained to the leading edge of the } \\
\text { undercut or to major structures }\end{array}$ \\
$\begin{array}{l}\text { Caving hydraulic } \\
\text { radius reached }\end{array}$ & $\begin{array}{l}\text { A more continuous seismogenic zone across the cave back } \\
\text { For a period, there will be an increase in seismic activity } \\
\text { An increase in the propagation rate and number of seismic events }\end{array}$ \\
$\begin{array}{l}\text { Initial propagation of } \\
\text { the cave }\end{array}$ & $\begin{array}{l}\text { An extension of the seismogenic zone along some peripheral major } \\
\text { structures } \\
\text { An increase in seismic activity below the extraction level }\end{array}$ \\
$\begin{array}{l}\text { Initial interaction } \\
\text { between the block } \\
\text { cave column and the } \\
\text { SLC column }\end{array}$ & $\begin{array}{l}\text { 'Stretching' of the seismogenic zone between the SLC column and block } \\
\text { cave column } \\
\text { Precursors to strong seismogenic interaction } \\
\text { Start of seismicity around the abutment of the cave } \\
\text { Changes in the rate of propagation of the seismogenic zone } \\
\text { Strong, front-scale seismogenic bridging between the SLC column and } \\
\text { beismogenic } \\
\text { bridging/strong } \\
\text { interaction }\end{array}$ \\
$\begin{array}{l}\text { This process is likely to progress very quickly and result in the greatest } \\
\text { seismic occurrence with large events similar to the 31 October 2013 event } \\
\text { Zone of loosening } \\
\text { spans block cave/SLC }\end{array}$ & $\begin{array}{l}\text { The development of more intense yielding between the SLC column and } \\
\text { block cave column results in a high seismogenic potential over a large } \\
\text { volume of rock covering the cave column } \\
\text { Following this stage, the breakthrough into the SLC shall occur }\end{array}$ \\
\hline
\end{tabular}

While a block cave is considered the best solution for the geotechnical environment at the production horizon, there is expected to be a seismic response as the cave propagates and converges with the SLC column. Similarly, as the cave matures there, is likely to be ongoing rock mass damage and subsidence effects on sections of currently accessible infrastructure. The assessment of these cave-induced hazards includes the proximity of excavations to the cave, the modelled rock mass damage, the modelled subsidence and exposure of excavations to seismic potential. Areas identified as being exposed to these hazards are addressed through a number of controls, including:

- Upgrade of excavations with dynamically capable ground support and reinforcement.

- Upgrade of the seismic monitoring system for proactive monitoring of stress change and loading.

- Detailed rock mass monitoring systems to confirm modelling results and aid in model calibration.

- Exclusion zones to remove personnel from the potential seismic hazards.

- Developing mine access/haulage bypasses around seismic hazard exposed areas.

Of note, sections of the current main Perseverance decline are situated to the west of the cave zone, and are intercepted by a number of unfavourable structures that are likely to be subject to dynamic loading events similar to those of 2013, during the life of the block cave. A hazard control has been developed to exclude these areas from operational personnel by bypassing these sections of decline that will be affected by the 
cave-induced seismicity. The bypass decline shown in orange in Figure 15 will make use of the Progress Decline (marked purple) which is positioned north and east of the modelled cave zone and path of the current Perseverance decline. The bypass is scheduled to be developed prior to the interaction with the cave growth to ensure that mine personnel are excluded from potentially hazardous areas.

Assessment of the seismic risk of the block cave indicates that it will not reach the levels of seismic response experienced during the final stages of SLC mining. The process for this assessment includes reviewing the numerical model for areas with high RER and to then interrogate these areas looking for large deformation potential. If the potential for deformation is large and the RER is high, there is a greater chance for damage from dynamic events. For the block cave, the potentially hazardous areas are associated with geological structures that intercept development and are adjacent to the SLC workings as the block cave column converges with SLC column. Figure 16 shows the total RER for the undercut and extraction levels at the end of block cave mining as compared to the RER generated during the final stages of the SLC. This indicates that levels of dynamic rock mass hazard are within levels that can be accounted for with conventional dynamic ground support and reinforcement schemes.

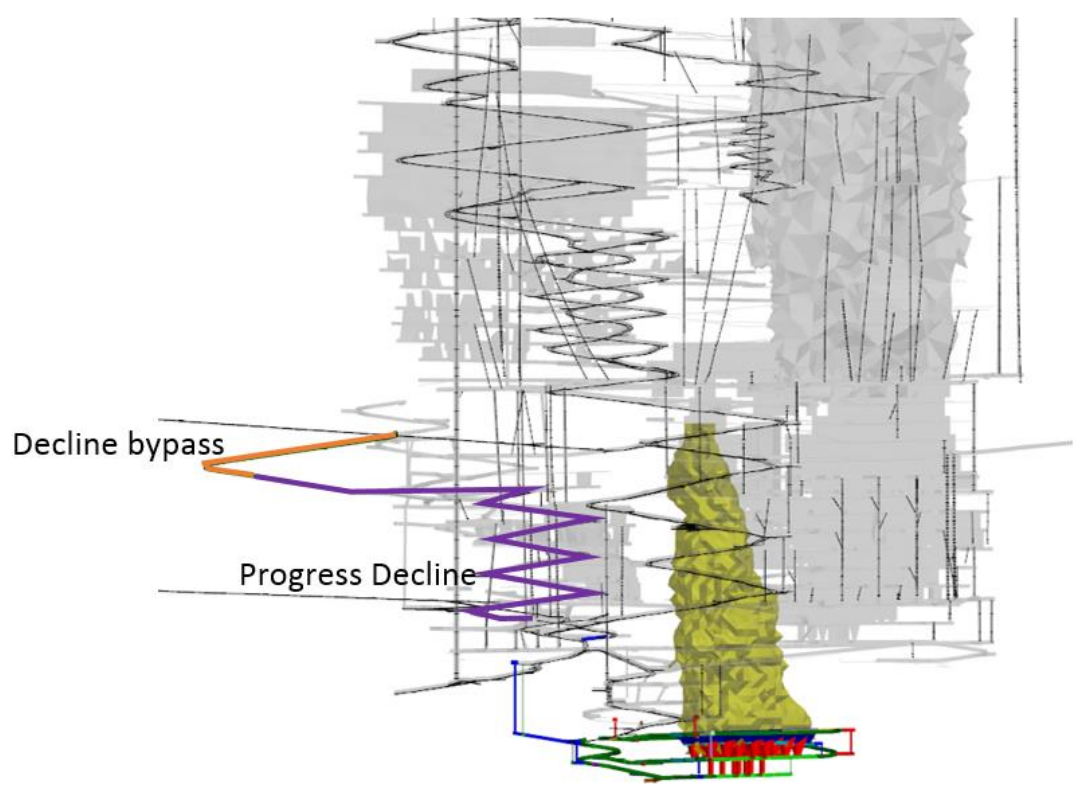

Figure 15 Decline bypass in relation to the block cave (looking east)

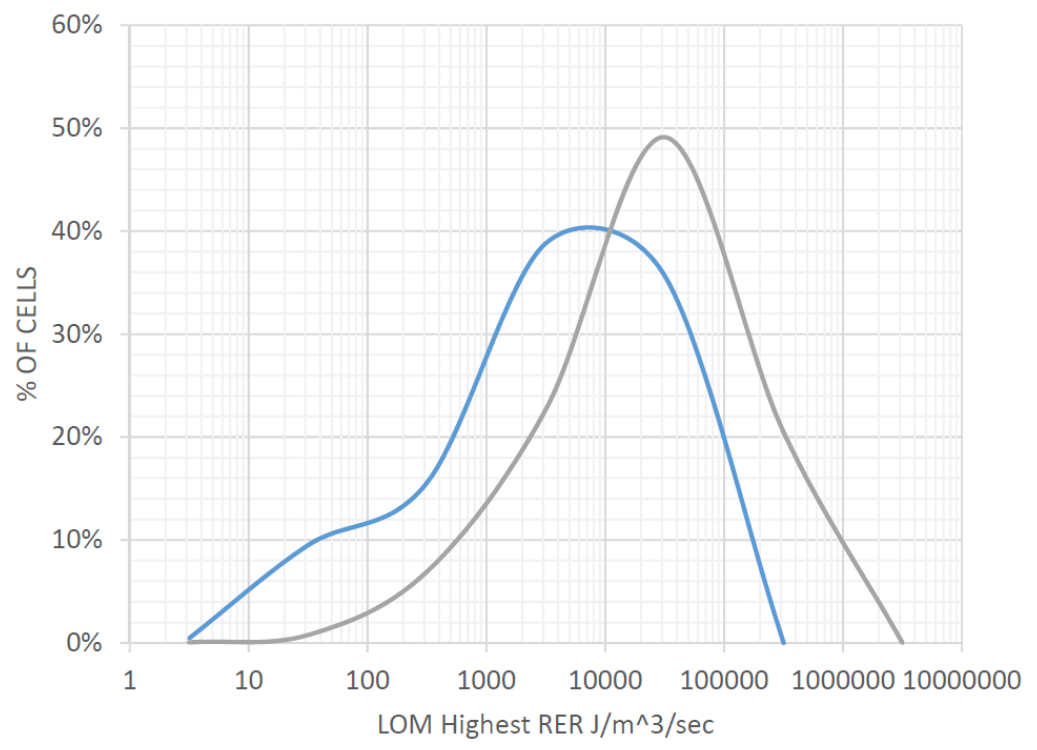

Figure 16 Comparison of life-of-mine highest RER for the block cave and final stages of SLC mining (blue - block cave, grey - SLC) 


\section{Conclusion}

The complex geological conditions through the 11 Level Fold, causing high stress and high seismic risk, required that an alternate mining method be developed that targets the ore remotely and removes personnel from the most at-risk areas of the mine. This case study has presented the historical context and mine plan rationale to show how the Leinster mining operation plans to extract the Perseverance resource by employing a block cave mining method.

A calibrated non-linear numerical model based on detailed geological and geomechanical models that forecasts rock mass response to mining has been developed to assess mining options and extraction sequences. A key tool in developing the block cave mine plan, the model has allowed forecasted seismic hazard and strain to be assessed to identify the most hazardous areas of the mine. These results have been used to develop a number of controls relating to mine design, production sequencing and seismic exclusions.

The block cave will be situated $150 \mathrm{~m}$ below and out of the stress influence of the 11 Level Fold. It will be developed with a mine design and extraction sequence that increases pillar thicknesses to reduce stress-related ground control issues and decreases the seismic response by retreating towards less seismically active rock types. The seismic response during block cave mining is assessed as being transient, with the initial response associated with the undercutting levels before occurring remotely to the production horizon during cave propagation.

The strongest seismic response is expected as the block cave column bridges and joins with the SLC column. Similar mechanisms to the 31 October 2013 event are expected during this phase. Hence, exclusions and development bypasses are planned to remove personnel from precincts of high dynamic rock hazard.

Seismic response of the block cave is not estimated to reach the levels seen in the SLC prior to cessation of mining. However, dynamic rock conditions are expected, and will be controlled with the implementation of dynamically capable ground support and reinforcement schemes throughout the production footprint.

\section{Acknowledgement}

Thanks is given to BHP Nickel West for allowing the authors to publish this paper.

\section{References}

Barton, N, Lien, R \& Lunde, J 1974, 'Engineering classification of rock masses for the design of tunnel support', Rock Mechanics, vol. 6, no. 4, pp. 189-236.

Beck, D 2013, BHP Billiton Nickel West: SLX Induced Seismic Hazard: Global Coupled Cave Flow (NCA) Rock Mass Deformation (DFE) Analysis, unpublished report, Beck Engineering, Chatswood West.

Beck, D 2017, Extraction of the Main Disseminated Orebody Below 11L by the Block Caving Method, unpublished report, Beck Engineering, Chatswood West.

Hoek, E, Kaiser, PK \& Bawden, WF 1995, Support of Underground Excavations in Hard Rock, A.A. Balkema, Rotterdam.

Laubscher, DH 1990, 'A geomechanics classification system for the rating of rock mass in mine design', Journal of the South African Institute of Mining and Metallurgy, vol. 90, no. 10, pp. 257-273.

Lessard, JF \& Heal, D 2009, 'Evolution of ground support practices within the development cycle at Perseverance Mine', in PM Dight (ed.), Proceedings of the First International Seminar on Safe and Rapid Development Mining, Australian Centre for Geomechanics, Perth, pp. 181-198.

Levkovitch, V, Beck, D \& Reusch, F 2013, 'Numerical simulation of the released energy in strain-softening rock materials and its application in estimating seismic hazard in mines', in A Malovichko \& DA Malovichko (eds), Proceedings of the 8th International Symposium on Rockbursts and Seismicity in Mines, Geophysical Survey of Russian Academy of Sciences, Obninsk, and Mining Institute of Ural Branch of Russian Academy of Sciences, Perm, pp. 259-266.

Struthers, MA, Turner, M, Jenkins, P \& McNabb, K 2000, 'Rock mechanics design and practice for squeezing ground and high stress conditions at Perseverance mine', Proceedings of MassMin 2000, The Australasian Institute of Mining and Metallurgy, Melbourne, pp. 755-764.

Thin, I, Stone, C, Beck, D \& Hastings, N 2006, 'Perseverance mine: past, Present and deeper - Part III', in Y Potvin (ed.), Proceedings of the 2nd International Seminar on Strategic Versus Tactical Approaches in Mining, Australian Centre for Geomechanics, Perth, Section 7, pp. 1-15.

Thin, I 2008, Definition Phase Study - Perseverance Deeps Project - Section 6 Geotechnical, unpublished report. 
Tyler, DB \& Werner, M 2004, 'A case study of ground support improvement at Perseverance mine', in E Villaescusa \& Y Potvin (eds), Proceedings of the Fifth International Symposium on Ground Support: Ground Support in Mining and Underground Construction, Taylor \& Francis Group, London, pp. 53-63.

Wood, P, Jenkins, P \& Jones, I 2000, 'Sub-level cave drop down strategy at Perseverance mine, Leinster Nickel Operations', Proceedings of MassMin 2000, The Australasian Institute of Mining and Metallurgy, Melbourne, pp. 517-526. 